\title{
Nilai Toleransi Beragama Dalam Tradisi Genduren Masyarakat Jawa Transmigran
}

\author{
Wahyudia, ${ }^{\mathrm{a}, *}$ \\ anstitut Agama Islam Ma'arif NU (IAIMNU) Metro Lampung \\ 'wahyudiragil447@gmail.com
}

ARTICLE INFO

Article history:

Received : 2019-01-22

Revised : 2019-12-24

Accepted : 2019-12-25

Keywords:

Genduren,

Teposeliro,

Transmigrant,

Javanese philosophy
Kata kunci:

Genduren,

Teposeliro,

Transmigran,

falsafah Jawa

\section{ABSTRACT}

This article discusses the value of tolerance in the genduren tradition, which is done by transmigrant Javanese society. The underlying problem of this study is that there are still many conflicts and acts of violence, because of differences in religious identity. The destruction of religious places of worship is a concrete evidence. This study uses a qualitative research method with a phenomenological approach as the analysis tool. The findings indicate that the behavior of genduren involved other religious people carried out by the Javanese transmigrants based on several factors. First, it is encouraged by the philosophy of Java teposeliro, one of the philosophies of Javanese society that teaches good relations with the environment, nature and fellow human beings. Second, religious models that tend to be secretive. Third, the environment developed by the predecessors is more inclusive so it opens harmonious relations with the predecessors.

\section{ABSTRAK}

Artikel ini membahas mengenai nilai toleransi dalam dalam tradisi genduren yang dilakukan oleh masyarakat Jawa transmigran. Masalah yang melatari dari kajian ini adalah karena masih banyak terjadi konflik dan tindakan kekerasan yang dilakukan karena perbedaan identitas agama. Perusakan terhadap tempat ibadah keagamaan merupakan bukti konkretnya. Penelitian ini menggunakan metode riset kualitatif dengan pendekatan fenomenologi sebagai pisau analisisnya. Hasil penelitian ini menunjukkan bahwa perilaku genduren melibatkan umat agama lain yang dilakukan oleh masyarakat Jawa transmigran didasari oleh beberapa faktor. Pertama didorong oleh falsafah jawa teposeliro, salah satu falsafah hidup masyarakat Jawa yang mengajarkan hubungan baik dengan lingkungan, alam dan sesama manusia. Kedua, model beragama yang cenderung sinkretis. Ketiga, lingkungan yang dikembangkan oleh para pendahulu lebih inklusif sehingga membuka hubungan harmonis dengan para pendahulu.

\section{Pendahuluan}

Toleransi beragama merupakan masalah krusial yang selalu menjadi isu hangat dewasa ini. Di Indonesia masalah toleransi agaknya masih menjadi problem bersama yang harus segera diselesaikan. Dalam rentan tahun 2018 di Indonesia sudah terjadi beberapa kasus intoleran dan kekerasan beragama. Di antaranya perusakan pura di Lumajang, penyerangan ulama di Lamongan, perusakan masjid di Tuban, ancaman bom di kelenteng Kwan Tee Koen di Karawang dan serangan gereja Santa Lidwina Sleman. (12) 
Kasus-kasus diatas menjadi raport merah di tengah beragam konflik yang terjadi di negeri ini. Dalam hasil rilis yang dilakukan oleh Setara Institute, paham radikalisme dan intoleran dalam beragama rawan menyerang generasi muda Indonesia saat ini.(21) Hal ini tentu menjadi problem bersama yang harus segera diselesaikan agar hubungan harmonis antar agama di negeri ini tetap terjaga.

Secara konseptual sebenarnya ada beragam cara untuk mewujudkan hubungan harmonis antar umat beragama. Diantaranya adalah dengan berbasis kearifan budaya lokal. Di Indonesia ada beragama kearifan budaya lokal yang mampu menjadi penggerak hubungan harmonis antar agama. Diantaranya adalah tradisi gendurenan.(9)

Genduren atau sebagian masyarakat jawa menyebutnya dengan kenduri merupakan sebuah tradisi berkumpul yang dilakukan oleh masyarakat jawa, biasanya didominasi oleh kaum laki-laki dengan tujuan meminta kelancaran atas hajat yang akan dilaksanakan oleh penyelenggara dan sebagai ungkapan rasa syukur atas nikmat yang diperoleh.(15) Tradisi ini merupakan warisan budaya jawa yang sudah dilakukan secara turun temurun. Genduren sebagai budaya memiliki sisi-sisi makna yang sesuai dengan ajaran agama Islam. Sehingga dalam perkembangannya sulit memisahkan antara budaya dan ajaran Islam dalam tradisi ini.

Hal tersebut sesuai dengan konsepsi Geertz yang menyatakan bahwa agama Islam jawa merupakan ekspresi keimanan, doktrin dan ritual yang dipraktikan masyarakat selaras dengan tradisi lokal.(14) Dengan demikian agama merupakan bagian dari sistem kebudayaan artinya agama menjadi kerangka penafsiran perbuatan manusia.(7) Sehingga agama atau kepercayaan memiliki fungsi memberikan signifikasi pemaknaan serta menawarkan penjelasan terhadap peristiwa atau pengalaman yang menyimpang dan tidak menyimpang dari tradisi.(16) Dalam genduren misalnya, agama memberikan signifikasi pemaknaan terhadap tradisi tersebut, serta mengupas nilai yang dapat diperoleh dari tradisi genduri yang sesuai dengan prinsip agama secara general.

Konsepsi Geertz akan agama hampir mirip dengan teori konstruksi sosial yang digagas oleh Berger dan Luckman. Berger dan Luckman menegaskan bahwa agama sebagai bagian dari budaya merupakan hasil dari konstruksi manusia. Artinya terdapat proses dialektika antara masyarakat dengan agama. Agama merupakan entitas objektif karena berada di luar manusia. Sebagai entitas objektif agama akan mengalami proses objektivisasi sebagiaan juga ketika agama berada dalam teks dan norma. Teks dan norma agama tersebut kemudian mengalami proses internalisasi ke dalam diri individu penganutnya karena telah diinterpretasi oleh manusia untuk menjadi guidance atau way of life. Agama juga mengalami proses eksternalisasi karena agama menjadi sesuatu yang shared di masyarakat. Sebagai hasil interpretasi maka norma agama tidak bisa lepas dari keadaan sosio-kultural dimana agama tersebut berkembang. Di Indonesia misalnya, agama menjadi identitas yang khas akan ke-Indonesia-annya sehingga muncul istilah Islam Nusantara, yang merupakan hasil bergumulan antara agama dan budaya di Indonesia.

Genduren merupakan salah satu produk dari interaksi agama dan budaya. Sebagai hasil interaksi antara agama dan budaya genduren memiliki banyak nilai-nilai luhur diantaranya, genduren menjadi media intregasi semua elemen masyarakat.(14) Hampir setiap acara masyarakat jawa, seperti nikahan dan khitanan diawali dengan genduren. Genduren menjadi semacam "pintu" acara yang dilaksanakan dengan harapan acara yang akan dilaksanakan berjalan dengan lancar. Biasanya dalam genduren masyarakat jawa menyediakan menu-menu khusus sesuai dengan hajat si empunya. Genduren menurut Woodward memiliki implikasi ekonomis bagi distribusi ekonomi atau dalam istilah Islam disebut dengan shadaqah.(19)

Mayoritas masyarakat jawa tetap memegang teguh tradisi genduren ini. Tidak terkecuali masyarakat jawa transmigran di Lampung Timur. Saat ini komunitas jawa di Lampung Timur memasuki generasi kedua. Artinya mayoritas suku jawa yang ada di Lampung Timur lahir dan besar di Lampung. Sebagai generasi yang jauh dari "pusat" tradisi jawa asli, dalam generasi ini telah banyak terjadi pergeseran budaya. Sehingga ada sebagian tradisi jawa yang sudah jarang 
digunakan lagi, seperti mencari hari baik untuk acara-acara besar tertentu. Banyak faktor yang mempengaruhi hal ini, di antaranya adalah para sesepuh suku jawa sudah banyak yang wafat dan tidak menurunkan ilmu ini kepada generasi selanjutnya. Namun beberapa tradisi seperti genduren masih dilestarikan oleh masyarakat jawa transmigran.

Di acara genduren tamu yang diundang diajak bersama-sama melantunkan ayat-ayat al-Qur'an, memohon doa keselamatan dan mengirim doa kepada para leluhur yang telah meninggal dunia. Sehingga meskipun genduren dianggap sebagai tradisi jawa namun ia sangat identik dengan agama Islam. Dengan demikian menarik untuk diteliti ketika genduren yang "dekat" dengan agama Islam namun dalam realitasnya masyarakat jawa transmigran di Lampung Timur melibatkan umat agama lain. Penelitian ini hendak menelaah konsepsi dan faktor-faktor apa yang mendorong masyarakat melakukan hal tersebut.

\section{Review Tinjauan Pustaka}

Sebenarnya peneliti bukan orang pertama yang membahas mengenai genduren. Sebelum peneliti, sudah ada peneliti lain yang membahas tentang genduren, diantaranya:

Skripsi yang ditulis oleh Andri Yanto dengan Judul Simbol-simbol Lingual Dalam Tuturan "Ujub Genduren" Siklus Hidup Masyarakat Saneporejo.(20) Dalam penelitian ini Andri Yanto fokus pada makna yang terkandung ujub genduren yang dilakukan masyarakat Saneporejo. Penelitian ini berbeda dengan penelitian penulis, fokus penelitian penulis adalah persepsi dan pemahaman masyarakat jawa transmigran tentang ayatayat yang dibaca dalam genduren, serta motif apa yang menjadi faktor pendorong masyarakat transmigran melibatkan penganut agama lain.

Penelitian yang dilakukan oleh Rina Dewi Susanti dengan judul Tradisi Kenduri dalam Masyarakat Jawa Pada Perayaan Hari Raya Galungan Kecamatan Tegaldlimo Kabupaten Banyuwangi (Kajian Teologi Hindu). Penelitian ini diterbitkan di Jurnal Penelitian Agama Hindu Institut Hindu Dharma Negeri Denpasar.(15) Dalam penelitian ini fokus pembahasannya adalah masyarakat jawa yang beragama Hindu dan berdomisili di Banyuwangi. Sementara penelitian yang akan penulis lakukan fokus kepada masyarakat jawa transmigran yang beragama Islam dan Berdomisili di Lampung Timur. Sehingga meskipun membahas tema yang sama (kenduri/genduren) namun objek dan lokasi penelitian berbeda.

Dalam penelitian ini, peneliti menjelaskan faktor-faktor apa yang mendorong masyarakat muslim jawa transmigran turut melibatkan umat agama lain dalam tradisi genduren.

\section{Metodologi Penelitian}

Penelitian ini adalah penelitian kualitatif dengan fenomenologi sebagai pisau analisisnya. Pendekatan fenomenologis yang dimaksud adalah upaya untuk menggambarkan makna dari pengalaman hidup beberapa individu tentang konsep dan fenomena tertentu, dengan mengeksplorasi struktur kesadaran manusia. Oleh karena itu, peneliti berupaya mengungkap kesadaran dari objek penelitian, mengetahui motivasi masyarakat jawa transmigran di Lampung Timur dalam melakukan tradisi genduren yang melibatkan umat agama lain.

Data dalam penelitian ini dikumpulkan melalui wawancara dengan stakeholder dan beberapa tokoh agama setempat serta masyarakat. Teknik pemilihan informan yang digunakan adalah teknik purposive sampling untuk mengarahkan pengumpulan data sesuai dengan maksud, kepentingan dan kebutuhan peneliti,(3)

\section{Hasil dan Diskusi}

Lampung merupakan salah satu provinsi yang menjadi tujuan transmigrasi penduduk Jawa sejak zaman kolonial Belanda. Proses perpindahan penduduk pulau Jawa ke Lampung pada era kolonialisme terbagi menjadi tiga tahap. Tahap pertama semua pembiayaan ditanggung oleh pemerintah. Tahap ini berlangsung pada tahun 1905 hingga tahun 1911. Tahap kedua pada tahun 1912-1928, dalam tahap ini pembiayaan berasal dari pinjaman dari bank. Tahap terakhir pada tahun 1932-1941, dengan sistem bawon.(8)

Setelah masa penjajahan Belanda berakhir, model pemerataan seperti ini tetap dilanjutkan 
oleh penjajah Jepang. Hanya saja pola yang digunakan berbeda. Pada masa Belanda perpindahan penduduk melibatkan keluarga bahkan bedol desa. Pada masa Jepang ini perpindahan hanya bersifat individual, hanya diperuntukan orang-orang yang masih kuat secara fisik.

Setelah kemerdekaan proses perpindahan penduduk masih tetap dilanjutkan dengan istilah transmigrasi. Pada masa Belanda perpindahan penduduk disebut dengan kolonialisme, sementara pada masa Jepang disebut dengan istilah kokuminggakari. Istilah pada masa penjajahan tersebut diganti dengan transmigrasi.

Transmigrasi ini membawa implikasi terjadinya interaksi antar budaya dan agama. Sehingga sering kali terjadi benturan-benturan antar agama dan budaya di daerah transmigran. Meskipun pada awalnya pemicunya bukan masalah agama, akan tetapi sentimen agama dan suku menjadikan benturan tersebut seolah-olah menjadi problem agama dan budaya. Misalnya kasus antar suku Lampung dan Bali beberapa tahun lalu di Lampung.(17)

Namun tidak selamanya interaksi antar budaya dan agama memunculkan benturanbenturan sebagaimana yang di atas. Kadang interaksi antara agama dan budaya terjalin secara inklusif dengan local wisdom sebagai basisnya. Misalnya yang terjadi dalam masyarakat transmigran di Lampung Timur.

Dalam hal interaksi antar agama masyarakat Lampung Timur menggunakan budaya sebagai basis toleransinya. Salah satunya adalah dengan budaya genduren. Budaya ini menjadi media dan aplikasi dari model beragama yang toleran, sebab masyarakat transmigran tidak hanya melibatkan satu pemeluk agama saja.

Nilai budaya dalam genduren turut memberikan pengaruh hubungan inklusif antar pemeluk agama.(2) Dalam konteks nilai budaya genduren ini ditemukan nilai budaya yang menjadi daya ikat terjalinnya kerukunan dan toleransi beragama.

Budaya genduren merupakan salah satu bentuk dari pola toleransi beragama aktif. Artinya toleransi beragama yang melibatkan diri dengan yang lain di tengah kemajemukan dan keberagaman agama. Ia tidak hanya mengakui secara faktual adanya beragam agama (toleransi pasif), tetapi pengakuan tersebut memuncul satu aksi berbaur di tengah keberagaman.

Dua model toleransi di atas dalam terminologi Ulil Absar Abdalla disebut dengan istilah pluralitas dan pluralisme. Mengakui bahwa masyarakat secara faktual memang berbeda adalah bentuk dari konsep pluralitas. Sementara sikap apa yang harus diambil dari kemajemukan tersebut merupakan ranah dari pluralisme.(1)

Dalam konteks masyarakat Jawa transmigran. Toleransi tidak hanya dalam tataran agree in disagreement. Tetapi sudah masuk ke dalam wilayah praktikal, sehingga tidak hanya dalam aspek pengakuan adanya pluralitas, meminjam nomenklatur Ulil Absar masyarakat Jawa Transmigran sudah masuk dalam konteks pluralisme.

Menurut Sutawi salah satu masyarakat Jawa transmigran yang beragama Kristen di Lampung Timur. Adanya genduren lintas agama ini menjadi hal yang positif di masyarakat. Meskipun penganut agama minoritas di daerah tersebut, ia tidak merasa didiskriminasi atau diisolasi oleh pemeluk agama mayoritas. Keterlibatannya dalam kegiatan genduren merupakan bukti bahwa masyarakat memiliki rasa toleransi yang tinggi.

Ia mengakui bahwa dalam tradisi genduren sangat kental dengan nuansa Islami. Namun ia tidak mempermasalahkan hal tersebut, baginya meskipun berada di tengah kegiatan umat Islam, bukan berarti secara otomatis agama yang dianutnya menjadi luntur.

Dari penuturan Sutawi dapat disimpulkan bahwa pemahamannya sudah masuk dalam ranah "rasionalisasi" agama. Ia memandang agama bukan dari sisi "magis" namun dari perspektif humanis. Ia tidak memandang ritual secara keagamaan (genduren) sebagai sesuatu yang penuh dengan kekuatan magis. Tetapi cenderung kepada satu nilai yang universal dan diterima oleh semua agama, yakni hidup rukun berdampingan dalam bermasyarakat.

Ada beragam motif masyarakat Jawa transmigran melibatkan umat agama lain dalam acara genduren. Di antaranya menghormati tetangga(11). Menurut Nurdin 
salah satu tokoh sepuh (tua) masyarakat Jawa transmigran, mengundang tetangga berbeda agama merupakan salah satu bentuk dari penghormatan. Dalam falsafah Jawa disebut dengan istilah teposeliro.

Perilaku mengundang umat agama lain dengan dasar falsafah teposeliro, mengindikasikan bahwa toleransi yang dikembangkan oleh masyarakat Jawa transmigran merupakan toleransi dengan sifat socialogis oriented.

Artinya toleransi yang dibangun atas dasar mengakui adanya pluralitas dan menghormati hak beribadah agama lain, dengan tujuan untuk mewujudkan keharmonisan bermasyarakat. Bukan toleransi yang bersifat theology oriented, yang menyatakan bahwa semua agama sama.

Ditinjau dalam perspektif teori konstruksi sosial, falsafah teposeliro suku Jawa tersebut diserap ke dalam (internalisasi) diri masyarakat Jawa transmigran. Kemudian menjadi pandangan hidup yang selanjutnya diekspersikan (eksternalisasi) melalui tindakan berupa melibatkan penganut agama lain dalam acara genduren.

Sementara meminjam teori unconciousness, dapat disimpulkan bahwa tradisi dan budaya merupakan produk dari collective unconciousness. Oleh karena itu untuk memahaminya memerlukan analisis sosiol-historis yang menyertainya.(6) Dalam tradisi genduren yang melibatkan umat agama lain misalnya, maka perlu dianalisis aspek sosial-historis yang menyertainya. Sehingga dapat diketahui faktor lain (selain teposeliro) yang mendorong masyarakat Jawa transmigran melakukan hal tersebut.

Secara sosial-historis masyarakat Jawa transmigran memasuki generasi kedua. Sebagai generasi kedua, maka banyak warisan budaya yang didapatkan dari generasi awal. Meskipun dalam proses transmisi budaya tersebut tidak terjadi seratus persen sebagaimana budaya awal generasi pertama. Banyak budaya-budaya yang sudah tidak "diperhatikan" oleh generasi kedua ini, misalnya penentuan hari baik untuk kegiatankegiatan penting.

Masyarakat Jawa transmigran generasi awal merupakan masyarakat Jawa yang masih memegang teguh budaya Jawa dengan model keberagamaan yang cenderung toleran dan singkretis. Kondisi sosial-historis yang demikian mendukung masyarakat untuk berperilaku toleran dalam interaksi antar agama. model beragama yang cenderung singkretis, membawa pemeluknya untuk bersifat toleran dengan kaum agama lain. Hal tersebut merupakan konsekuensi logis dari proses keterbukaan sehingga terjadi dialog agama dan budaya.

Geertz yang menyatakan bahwa agama Islam jawa merupakan ekspresi keimanan, doktrin dan ritual yang dipraktikan masyarakat selaras dengan tradisi lokal. Secara tidak langsung Geertz menyatakan bahwa model keagamaan masyarakat Jawa merupakan hasil dari asimilasi antara budaya dan agama.

Hal tersebut tentu berbeda dengan model beragama yang cenderung puritan dan scriptualisme. Kaum beragama yang bergenre puritan dan scriptualisme cenderung kurang akomodatif terhadap budaya-budaya lokal. Bagi mereka beragama harus benarbenar "bersih" dari berbagai macam atribut budaya.(18) Model berpikir seperti ini berimplikasi terhadap sikap kepada umat agama lain.

Kaum scriptualisme cenderung eksklusif dalam interaksi antar agama. Bahkan dalam tataran tertentu memperbolehkan membunuh umat agama lain dengan dalih perjuangan menegakan agama. Kondisi sosial seperti ini tentu tidak memberikan ruang yang luas untuk agama lain berbaur dalam kegiatan umat Islam.

Dengan demikian, setting-sosial dan setting historis turut memberikan kontribusi dalam mengkonstruksi pola pikir dan tindak laku masyarakat. Masyarakat tidak mungkin melepaskan diri dari "kurungan" ini. Setting sosial yang toleran dan harmonis akan membentuk individu-individu yang toleran pula.

Kondisi lingkungan sosial masyarakat Jawa transmigran yang sedemikian rupa, memungkinkan masyarakat untuk berperilaku toleran terhadap umat agama lain. Sebab lingkungan dan manusia merupakan dua intensitas yang terus saling berinteraksi dan mempengaruhi. Perilaku manusia dapat menyebabkan perubahan lingkungan(10) dan 
sebaliknya lingkungan juga mampu merubah pola pikir dan perilaku manusia.

\section{Kesimpulan}

Toleransi aktif yang dilakukan oleh masyarakat Jawa transmigran dengan melibatkan penganut agama lain, setidaknya dipengaruhi oleh dua faktor utama. Pertama falsafah hidup suku Jawa, teposeliro. Falsafah ini mendorong masyarakat Jawa untuk peduli dengan sesama dan lingkungan, tanpa mempermasalahkan status agama yang dianut.

Faktor yang kedua adalah setting-sosial yang mendukung. Model beragama yang cenderung singkretis memberikan kontribusi dalam mengkonstruksi pola pikir yang toleran kepada masyarakat transmigran. Dalam sisi tertentu singkretis mungkin menjadi problem bagi kalangan beragama, namun di sisi lain model beragama seperti ini memberikan cara pandang terbuka yang cenderung menerima secara legowo perbedaan. Hal ini menunjukan bahwa cara pemahaman agama turut memberikan andil dalam sikap dan perilaku masyarakat. Selain itu, falsafah budaya lokal juga turut memberikan signifikasi dalam hubungan harmonis antar sesama pemeluk agama.

\section{Daftar Pustaka}

1. Abdalla UA. Pluralisme dan Pluraliras: dua dari koin yang sama [Online]. IslamLib.com: [3 Jan. 2019].

2. Ajahari. Aktualisasi Kerukunan Masyarakat Beda Agama di Kelurahan Pager Kecamatan Rangkupit Kota Palangka Raya. Jurnal Studi Agama dan Masyarakat 14, 2018.

3. Ali M. Memahami Riset Pelaku dan Sosial. Jakarta: Bumi Aksara, 2014.

4. Berger PL. Langit Suci: Agama sebagai Realitas Sosial. Jakarta: LP3ES, 1991.

5. Casram C. Membangun Sikap Toleransi Beragama dalam Masyarakat Plural. Wawasan: Jurnal Ilmiah Agama dan Sosial Budaya 1: 187-198, 2016.
6. Faiz F. Hermeneutika Al-Qur'an Tema-Tema Kontroversial. Yogyakarta: el-Saq, 2005.

7. Geertz C. The Interpretation of Culture. New York: Basic Books, 1970.

8. Halwi Dahlan M. Perpindahan Penduduk Dalam Tiga Masa: Kolonisasi, Kokuminggakari, Dan Transmigrasi Di Provinsi Lampung (1905-1979). Patanjala : Jurnal Penelitian Sejarah dan Budaya 6: 335, 2014.

9. Masduki. Toleransi di Masyarakat Plural Berbasis Budaya Lokal. Jurnal Sosial Budaya 14, 2017.

10. Nuqul FL. Pengaruh Lingkungan Terhadap Perilaku Manusia: Studi Terhadap Perilaku Penonton Bioskop.PSIKOISLAMIKA : Jurnal Psikologi dan Psikologi Islam. 2, 2005.

11. Nurdin. Genduren. 2018.

12. Rochmanudin. Kasus Intoleransi dan Kekerasan Beragama Sepanjang 2018 https://www.idntimes.com/news/indone sia/rochmanudin-wijaya/linimasakasus-intoleransi-dan-kekerasanberagama-sepanjang-2/full [3 Jan. 2019].

13. Setiohastorahmanto $\mathbf{P}$, Sugiono Soetomo, Agung Budi Sardjono. Ruang Andangan Arsitektur Limasan Sebagai Wadah Tradisi Kalang Etnografi Demang Kalang (sub etnis Jawa). Jurnal Arsitektur Zonasi 1, 2018.

14. Sumbulah U. Islam Jawa dan Akulturasi Budaya: Karakteristik Variasi dan Ketaatan Ekspresi. 14, 2012.

15. Susanti RD. Tradisi Kenduri Dalam Masyarakat Jawa Pada Perayaan Hari Raya Galungan di Desa Purwosari Kecamatan Tegal Dlimo Kabupaten Banyuwangi. Jurnal Penelitian Agama Hindu 1, 2017. 
16. Sutiyono. Benturan Budaya Islam Puritan dan Sinkretis. Jakarta: Kompas, 2010.

17. Tempo.co. Pemicu Bentrokan Lampung Versi

Pendudukhttps://nasional.tempo.co/rea d/439069/pemicu-bentrokan-lampungversi-penduduk/full\&view=ok [12 Jan. 2019].

18. Tri Haryanto J. Relationship, Transformation and Adaptation of The Traditionalists Against Puritanism in Surakarta Indonesia. Analisa 22: 239, 2015.

19. Woodward MR. Islam In Java; Normative Piety and Myticism in the
Sultanate of Yogyakarta. Tucson: The University of Arisona Press, 1998.

20. Yanto A. Simbol-simbol Lingual Dalam Tuturan "Ujub Genduren" Siklus Hidup Masyarakat Saneporejo. Jember: Universitas Jember Jurusan Pendidikan Bahasa dan Seni, 2015.

21. Jelang Pemilu, Generasi Milenial Rawan Terpapar Virus Intoleransi http://setara-institute.org/jelang-pemilugenerasi-milenial-rawan-terpapar-virusintoleransi/\# [3 Jan. 2019]. 